\title{
Liquid Presenting as Solid: A Rare Presentation of Acute Myeloid Leukaemia as a Solid Epidural Mass
}

\author{
Varsha Gupta ${ }^{1}$, Firas Ajam ${ }^{1}$, Gabriella Conte ${ }^{1}$, Alsadiq Al Hillan ${ }^{1}$, Kadhim Al-Banaa ${ }^{2}$, Vinit Singh ${ }^{3}$, Michael Levitt ${ }^{4}$ \\ ${ }^{1}$ Department of Medicine, Jersey Shore University Medical Center, Neptune, NJ, USA \\ ${ }^{2}$ Department of Medicine, Beaumont Hospital, Dearborn, MI, USA \\ ${ }^{3}$ Department of Internal Medicine, Section of Medical Oncology, Yale School of Medicine, CT, USA \\ ${ }^{4}$ Division of Hematology and Oncology, Jersey Shore University Medical Center, Neptune, NJ, USA
}

Received: $13 / 06 / 2020$

Accepted: 04/08/2020

Published: 08/09/2020

How to cite this article: Gupta V, Ajam F, Conte G, Al Hillan A, Al-Banaa K, Singh V, Levitt M. Liquid presenting as solid: a rare presentation of acute myeloid leukaemia as a solid epidural mass . EJCRIM 2020;7: doi:10.12890/2020_001802.

Conflicts of Interests: The Authors declare that there are no competing interests.

This article is licensed under a Commons Attribution Non-Commercial 4.0 License

\section{ABSTRACT}

Myeloid sarcoma (MS) is a very rare malignant tumour composed of myeloblasts. It most commonly involves soft tissue, bone, periosteum and lymph nodes, but unusual presentation sites have also been reported. Typically, MS evolves concurrently with active leukaemia or following remission, when it is known as secondary MS. But rarely MS can occur de novo without evidence of concomitant haematological disease. Herein, we report an unusual case of central nervous system-MS in a patient without evidence of concomitant haematological disease. In this case, progressive thoracic and lumbar pain with paraplegia ultimately led to the diagnosis of acute myeloid leukaemia. We also conducted a PubMed search for case reports, case series and reviews of past literature regarding central nervous system-MS and report our findings.

\section{LEARNING POINTS}

- Myeloid sarcoma (MS) can present de novo in the absence of antecedent leukaemia.

- Clinical manifestations of neural MS can be variable, including rare ones like spinal cord compression.

- Timely recognition of MS is paramount, as it is potentially curable.

\section{KEYWORDS}

Central nervous system-myeloid sarcoma, chloroma, granulocytic sarcoma, acute myeloid leukaemia

\section{INTRODUCTION}

Myeloid sarcoma (MS) is a very rare extramedullary manifestation $(<1 \%)$ of acute myeloid leukaemia ${ }^{[1,2]}$. MS results from the proliferation of myeloid blast cells at an anatomical site other than the bone marrow, including soft tissue, the musculoskeletal system and the central nervous system ${ }^{[1]}$. Central nervous system-MS was first described in 1811 by British physician A Burns, and later in 1853 King coined the term 'chloroma' due to its green tint in the presence of myeloperoxidase ${ }^{[3,4]}$. Rappaport later named this entity 'granulocytic sarcoma' to describe tumours of granulocytic origin, which are currently associated with acute myeloid leukaemia, myelodysplastic syndrome or myeloproliferative disorders ${ }^{[5]}$. MS most commonly involves the soft tissue, bone, periosteum and lymph nodes, but unusual presentation sites in the breast, pancreas and urinary bladder have also been reported ${ }^{[6-9]}$. Newly diagnosed MS of the central nervous system is very 
rare, with a reported incidence of $3.25 \%$ in patients ${ }^{[10]}$. It is distinctly rare for such tumours to cause epidural compression as the initial manifestation of disease, especially in patients without the presence of a haematological disorder during hospitalization.

\section{CASE DESCRIPTION}

A 59-year-old man with history of diabetes, atrial fibrillation and lower back pain worsening for 2-3 months presented with sudden onset paraplegia, lower extremity numbness and urinary incontinence. On physical examination, bilateral lower extremity muscle strength was $0 / 5$, sensation to pain and touch was absent, and deep tendon reflexes were also absent bilaterally in the lower extremities. Upper extremity and cranial nerve examination was normal. Laboratory studies showed haemoglobin $14.1 \mathrm{~g} / \mathrm{dl}$, white blood cell count $14.8 \mathrm{~K} /$ $\mu \mathrm{l}$, platelet count $162 \mathrm{~K} / \mu \mathrm{l}$, haematocrit $42.6 \%$, sodium $135 \mathrm{mmol} / \mathrm{l}$, and creatinine $0.91 \mathrm{mg} / \mathrm{dl}$. Magnetic resonance imaging of the spine (Fig. 1) revealed epidural masses extending from the level of T7 to T10 with spinal stenosis and cord compression, and another epidural mass at the L2 vertebra. The patient underwent laminectomies and resection of the masses. Biopsy of the L2 mass (Fig. 2) showed a high-grade malignant neoplasm invading the skeletal muscle consistent with chloroma. Immunophenotyping was positive for $C D$ (cluster of differentiation) 45, CD117, CD43 and myeloperoxidase (MPO). It was negative for CD34. A diagnosis of acute myeloid leukaemia was made. Bone marrow biopsy was consistent with acute myeloid leukaemia as well. Flow cytometry showed blasts accounted for $77 \%$ of cells and was positive for CD11c, CD4, CD33, HLA-DR (human leukocyte antigen-DR isotype), CD117, CD13, CD38 and MPO. Fluorescence in situ hybridization (FISH) testing was negative. The cytogenetic profile showed a normal male karyotype 46,XY. The molecular profile was consistent with NPM1 (nucleophosmin 1) mutation, indicating good prognosis. The day after resection of the epidural mass, the patient's pain resolved, but the numbness and weakness in his legs persisted. He was subsequently transferred to an advanced facility for chemotherapy with a combination of fludarabine, cytarabine, idarubicin, and granulocyte colony-stimulating factor (G-CSF) (FLAG-IDA) and intrathecal cytarabine (Ara-C). The patient showed remarkable improvement in his symptoms. A repeat bone marrow biopsy showed remission.

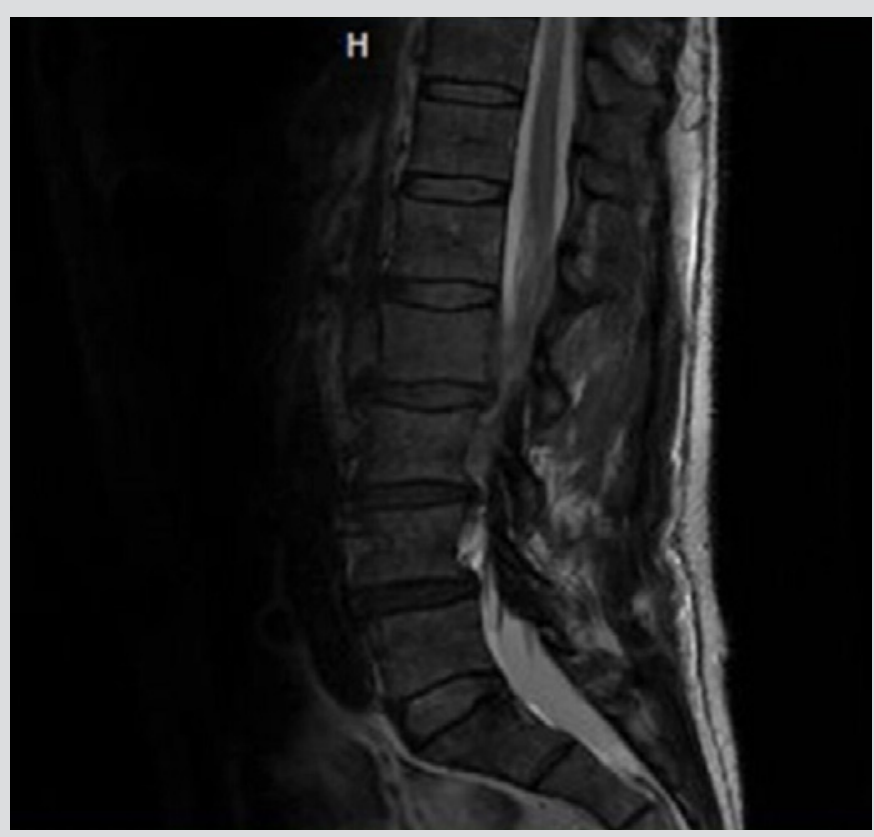

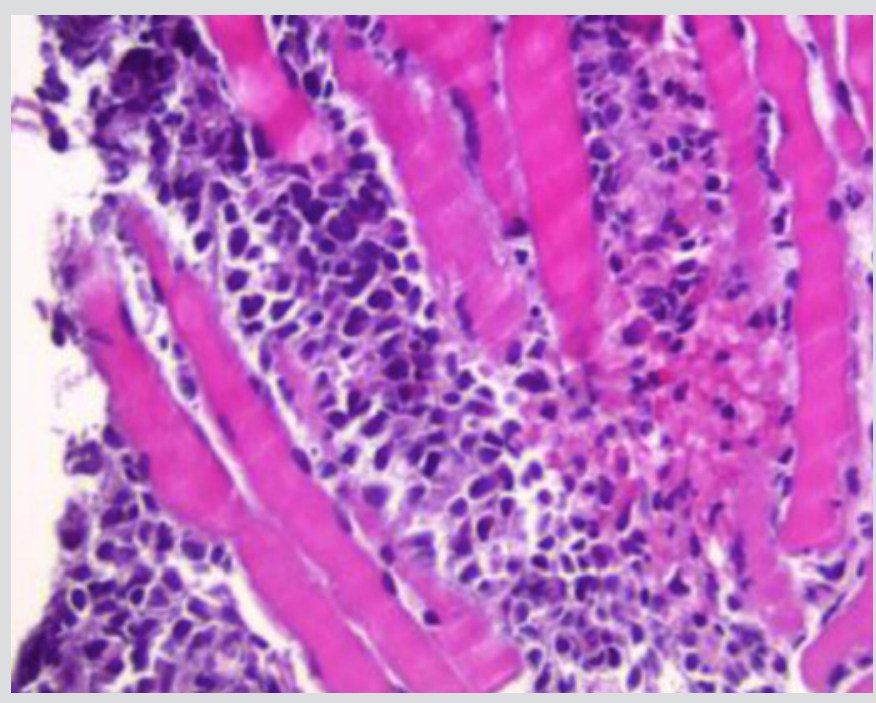

Figure 2. Epidural mass resection at the level of $L 2$, showing a high-grade malignant neoplasm invading the skeletal muscle tissue consistent with myeloid sarcoma

Figure 1. MRI of the spine showing an epidural mass at the level of $L 2$

\section{DISCUSSION}

Myeloid sarcoma (MS) is a rare condition characterized by the presence of solitary or multiple tumours consisting of immature myeloid cells, at an extramedullary site. The clinical manifestations of MS are diverse given the various sites of occurrence, with signs and symptoms determined by its specific location and size. These sites could be almost every part of the body ${ }^{[11]}$. The most common sites of MS presentation are skin (28.2\%), lymph node (16.3\%), testis (6.5\%), intestine (6.5\%), bone (3.25\%) and central nervous system (3.25\%)

[12]. Symptoms usually occur as result of mass effect or organ damage. 
MS may develop de novo, that is, it is present before clinical signs of leukaemia and in association with a normal bone marrow biopsy and blood film, and is also known as primary or isolated $\mathrm{MS}^{[11]}$. Most commonly, it occurs concurrently with acute myeloid leukaemia, myeloproliferative disorder or myelodysplastic syndrome ${ }^{[12-15]}$. When associated with acute myeloid leukaemia, it may present as the first evidence of acute myeloid leukaemia or may precede it. It may also represent relapse in a previously treated acute myeloid leukaemia.

Although a rare entity, the incidence of MS has risen lately according to the literature. This could be secondary to the likelihood of acute myeloid leukaemia relapse at an extramedullary site after haematogeneic stem cell transplantation or therapy with novel targeted agents ${ }^{[11]}$. Central nervous system-MS is suggested to occur when leukaemic cells pass from the bone marrow of the skull to the dura, subarachnoid space and Virchow-Robin spaces, resulting in invasion of the brain surface ${ }^{[16]}$. However, the pathogenesis for the occurrence of de novo myeloid sarcoma is still unclear.

MS is very frequently misdiagnosed as lymphoma, especially when there is no evidence of antecedent haematological malignancy. The differential diagnosis of MS includes non-Hodgkin lymphoma, lymphoblastic leukaemia, melanoma, Ewing sarcoma and blastic plasmacytoid dendritic cell neoplasm.

The diagnosis of MS is based on clinic symptoms, radiological investigations and tissue biopsy. A very elaborate evaluation including immunohistochemistry, flow cytometry, FISH and molecular analysis is needed. Bone marrow biopsy should be performed in all patients with MS. Complete work-up helps to both stratify risk and specify targeted therapy.

Pileri et al. studied MS morphologically and immunohistochemically ${ }^{[10]}$. The blastic variant was the most common form, followed by the monoblastic and myelomonocytic variants. The study also confirmed the importance of markers like myeloperoxidase (MPO), CD117 and CD68PG-M1 for diagnosis ${ }^{[10]}$. MPO is expressed in 66-96\% of MS cases and is responsible for its greenish appearance when exposed to air. Other antigens expressed in MS are CD43, lysozyme, CD11c, CD13 and CD33 ${ }^{[11]}$. Mutated nucleophosmin 1 (NPM1) is the most frequent mutation reported in $\mathrm{MS}^{[11]}$. MS is commonly associated with the translocation $\mathrm{t}(8 ; 21)(\mathrm{q} 22 ; \mathrm{q} 22)^{[11,17]}$.

MS is a rare neoplasm, so our knowledge is limited and mostly based on previous case reports and retrospective studies. Prior studies have suggested prognostic differences based on the site of involvement ${ }^{[11]}$. Median overall survival for some of the disease sites, like the reproductive and digestive systems, is better than for nervous system and soft tissue involvement ${ }^{[2]}$. Some studies have also correlated a prior history of myelodysplastic syndrome and myeloproliferative neoplasms as a negative prognostic factor ${ }^{[11]}$. Early diagnosis and treatment is associated with a significantly lower probability of developing acute myeloid leukaemia and with longer survival[18]. Untreated MS typically transforms to acute myeloid leukaemia in 10-12 months ${ }^{[11]}$.

Treatment of MS is dependent on various factors including the site and size of MS, the patient's age, relation to local structures, timing of diagnosis, concurrent acute myeloid leukaemia and performance status of the patient. Broadly, management includes local therapy with surgery or radiotherapy, as well as systemic chemotherapy. Current guidelines recommend initial treatment with induction chemotherapy for all patients diagnosed with extramedullary $\mathrm{MS}^{[2]}$. Chemotherapy should be started as soon as possible. Some trials have shown an encouraging prognosis with allogenic haematopoietic stem cell transplantation after induction chemotherapy ${ }^{[11]}$. Pileri et al. showed better overall survival at 48 months for patients receiving allogenic stem cell transplantation when compared with patients not receiving transplantation ${ }^{[10]}$. Opportunities for targeted therapy against MS are still very limited because of its rarity and lack of available data ${ }^{[11]}$.

The literature on central nervous system-MS consists only of a few case reports and a few case series. We performed a literature search for the last 10 years in PubMed using the keywords "myeloid sarcoma", "chloroma", "granulocytic sarcoma" AND "CNS". We selected MS cases with enough information available for follow-up. We looked for the following: (a) age at diagnosis; (b) presence/absence at diagnosis of haematological neoplasia; (c) type of haematological neoplasia; (d) time to MS; (e) clinical presentation; (f) site of involvement; (g) pathological findings; (h) treatment; and (i) outcome.

Olar et al. reported 12 cases of central nervous system-MS in a review article ${ }^{[19]}$. The median age at diagnosis was 42.5 years. One patient was lost to follow-up. Only three out of 12 patients had a diagnosis of prior haematological neoplasia. Neurological symptoms were related to the anatomical structures involved. Out of 12 cases, spinal cord involvement was evidenced in five cases. Treatment modalities chosen for these patients included surgery for two cases, radiotherapy for two, and seven received chemotherapy. Nine out of 12 patients died within 3 days to 12 months following MS diagnosis. Two patients were alive without evidence of disease.

Cervantes et al. reported 21 reported cases of myeloid sarcoma in patients with acute myeloid leukaemia. The mean age at the time of diagnosis was 35. Twelve out of 21 patients had pre-existing acute myeloid leukaemia, and eight patients presented with neurological symptoms ${ }^{[13]}$. The authors also reported three patients from their own institution, as described in Table 1.

\section{CONCLUSION}

In the absence of antecedent leukaemia, establishing the diagnosis can be challenging. It is therefore important to maintain a high index of suspicion to avoid misdiagnosis. Establishing a diagnosis is difficult as MS can easily mimic primary central nervous system neoplasms and lymphomas. Timely recognition is paramount as MS is potentially curable. 


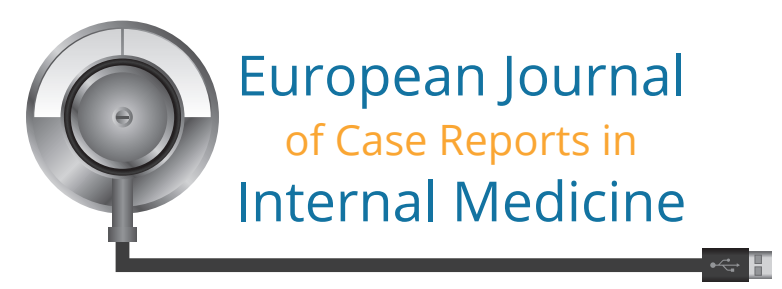

\begin{tabular}{|c|c|c|c|c|c|c|c|c|}
\hline $\begin{array}{l}\text { Age and sex } \\
\text { (reference } \\
\text { number) }\end{array}$ & $\begin{array}{c}\text { Presence of } \\
\text { haematological } \\
\text { neoplasia }\end{array}$ & $\begin{array}{c}\text { Type of } \\
\text { haematological } \\
\text { neoplasia }\end{array}$ & Time to MS & $\begin{array}{c}\text { Clinical } \\
\text { presentation }\end{array}$ & $\begin{array}{c}\text { Site of } \\
\text { involvement }\end{array}$ & Pathology & Treatment & Outcome \\
\hline $5 \mathrm{M}$ [17] & Yes & $\begin{array}{l}\text { Acute myeloid } \\
\text { leukaemia }\end{array}$ & $\begin{array}{l}\text { Diagnosed at the } \\
\text { same time }\end{array}$ & $\begin{array}{c}\text { Headache, } \\
\text { lower extremity } \\
\text { weakness, altered } \\
\text { mental status }\end{array}$ & Intracranial & $\begin{array}{c}\text { Bone marrow } \\
\text { biopsy: AML with } \\
\text { t(8;21); RUNX1 } \\
\text { (Runt-related } \\
\text { transcription factor } \\
\text { 1)/RUNX1T1 } \\
\text { (Runt-related } \\
\text { transcription factor } \\
1 \text { translocation } \\
\text { partner } 1 \text { ) }\end{array}$ & $\begin{array}{c}\text { Chemotherapy and } \\
\text { radiotherapy }\end{array}$ & $\begin{array}{c}\text { Remission, no } \\
\text { neurological } \\
\text { symptoms }\end{array}$ \\
\hline $69 \mathrm{~F}[13]$ & Yes & $\begin{array}{l}\text { Acute myeloid } \\
\text { leukaemia }\end{array}$ & Not known & Headache & $\begin{array}{l}\text { Intracranial } \\
\text { meningeal }\end{array}$ & Not known & Chemotherapy & Remission \\
\hline $56 \mathrm{~F}[13]$ & Yes & $\begin{array}{l}\text { Acute myeloid } \\
\text { leukaemia }\end{array}$ & Not known & $\begin{array}{l}\text { Headache and } \\
\text { weakness }\end{array}$ & Intracranial & Not known & Not known & Not known \\
\hline $53 \mathrm{M}$ [13] & Yes & $\begin{array}{l}\text { Myelodysplastic } \\
\text { syndrome }\end{array}$ & Not known & Diabetes insipidus & Neurohypophysis & Not known & Not known & Not known \\
\hline $54 \mathrm{M}$ [20] & Yes & $\begin{array}{l}\text { Chronic myeloid } \\
\text { leukaemia }\end{array}$ & 2 months & Headache & Intracranial & $\begin{array}{l}\text { Intracranial mass } \\
\text { consistent with } \\
\text { myeloid sarcoma }\end{array}$ & Surgery & Withdrawal of care \\
\hline $54 \mathrm{M}[21]$ & Yes & $\begin{array}{l}\text { JAK } 2 \text { V617F } \\
\text { (Janus Kinase } \\
2 \text { mutation p. } \\
\text { Val617Phe) }\end{array}$ & 13 years & $\begin{array}{l}\text { 3rd cranial nerve } \\
\text { palsy }\end{array}$ & Intracranial & $\begin{array}{l}\text { Intracranial } \\
\text { mass consistent } \\
\text { with MS with } \\
\text { megakaryoblastic } \\
\text { differentiation }\end{array}$ & $\begin{array}{l}\text { Surgery and } \\
\text { chemotherapy }\end{array}$ & $\begin{array}{c}\text { Acute blastic } \\
\text { leukaemic } \\
\text { transformation and } \\
\text { eventual death }\end{array}$ \\
\hline $27 \mathrm{M}[16]$ & No & N/A & N/A & $\begin{array}{l}\text { Weakness of lower } \\
\text { extremities }\end{array}$ & $\begin{array}{l}\text { Spinal mass } \\
\mathrm{T} 12-\mathrm{S} 1\end{array}$ & $\begin{array}{c}\text { Biopsy proven } \\
\text { myeloid sarcoma, } \\
\text { with positive } \\
\text { staining for } \\
\text { myeloperoxidase, } \\
\text { leukocyte common } \\
\text { antigen, lysozyme, } \\
\text { and CD10, 56, 68, } \\
99 \text { and } 117\end{array}$ & $\begin{array}{l}\text { Surgery and } \\
\text { chemotherapy }\end{array}$ & $\begin{array}{l}\text { Improvement of } \\
\text { symptoms }\end{array}$ \\
\hline $27 \mathrm{M}[16]$ & Yes & $\begin{array}{c}\text { Acute myeloid } \\
\text { leukaemia } \\
\text { diagnosed } 12 \\
\text { months after MS }\end{array}$ & De novo & $\begin{array}{l}\text { Rt. tinnitus and } \\
\text { hearing loss }\end{array}$ & $\begin{array}{c}\text { Mass at right } \\
\text { cerebello-pontine } \\
\text { angle }\end{array}$ & $\begin{array}{l}\text { Biopsy proven } \\
\text { myeloid sarcoma, } \\
\text { with positive } \\
\text { staining for } \\
\text { myeloperoxidase, } \\
\text { Leber congenital } \\
\text { amaurosis, } \\
\text { lysozyme, and } \\
\text { CD10, CD33, } \\
\text { CD38, CD45, } \\
\text { CD56, CD68, } \\
\text { CD99 and CD117 }\end{array}$ & Subtotal resection & Recurrence \\
\hline $54 \mathrm{M}$ [16] & No & N/A & N/A & $\begin{array}{l}\text { Left lower } \\
\text { extremity } \\
\text { weakness and } \\
\text { numbness }\end{array}$ & $\begin{array}{l}\text { Masses at L1, L3, } \\
\text { S1-S2 }\end{array}$ & $\begin{array}{l}\text { Biopsy proven } \\
\text { myeloid sarcoma, } \\
\text { with positive } \\
\text { staining for } \\
\text { myeloperoxidase, } \\
\text { Leber congenital } \\
\text { amaurosis, } \\
\text { lysozyme, and } \\
\text { CD3, CD10, CD33, } \\
\text { CD34, CD38, } \\
\text { CD45, CD56, } \\
\text { CD68, CD99 and } \\
\text { CD117 }\end{array}$ & Partial resection & $\begin{array}{l}\text { Improvement of } \\
\text { symptoms }\end{array}$ \\
\hline
\end{tabular}




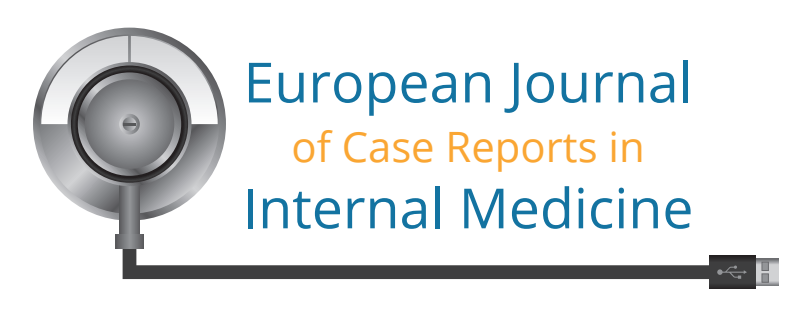

\begin{tabular}{|c|c|c|c|c|c|c|c|c|}
\hline $\begin{array}{l}\text { Age and sex } \\
\text { (reference } \\
\text { number) }\end{array}$ & $\begin{array}{c}\text { Presence of } \\
\text { haematological } \\
\text { neoplasia }\end{array}$ & $\begin{array}{c}\text { Type of } \\
\text { haematological } \\
\text { neoplasia }\end{array}$ & Time to MS & $\begin{array}{c}\text { Clinical } \\
\text { presentation }\end{array}$ & $\begin{array}{c}\text { Site of } \\
\text { involvement }\end{array}$ & Pathology & Treatment & Outcome \\
\hline $6 \mathrm{~F}[16]$ & No & N/A & $\mathrm{N} / \mathrm{A}$ & Headache & $\begin{array}{l}\text { Mass at parietal } \\
\text { lobe, left orbit, } \\
\text { sphenoid sinus }\end{array}$ & $\begin{array}{l}\text { Biopsy proven } \\
\text { myeloid sarcoma, } \\
\text { with positive } \\
\text { staining for } \\
\text { myeloperoxidase, } \\
\text { Leber congenital } \\
\text { amaurosis, } \\
\text { lysozyme, and } \\
\text { CD10, CD33, } \\
\text { CD34, CD45, } \\
\text { CD68, CD99 and } \\
\text { CD117 }\end{array}$ & Subtotal resection & $\begin{array}{l}\text { Improvement of } \\
\text { symptoms }\end{array}$ \\
\hline $50 \mathrm{~F}[22]$ & Yes & $\begin{array}{l}\text { Chronic myeloid } \\
\text { leukaemia }\end{array}$ & 6 Months & $\begin{array}{l}\text { Facial and } \\
\text { extremity } \\
\text { weakness }\end{array}$ & $\begin{array}{l}\text { Mass at frontal } \\
\text { lobe }\end{array}$ & $\begin{array}{l}\text { Biopsy proven MS } \\
\text { with positive for } \\
\text { glial fibrillary acidic } \\
\text { protein, CD45, and } \\
\text { CD31 }\end{array}$ & Surgical resection & $\begin{array}{l}\text { Improvement of } \\
\text { symptoms }\end{array}$ \\
\hline $27 \mathrm{M}$ [12] & No & N/A & De novo & $\begin{array}{c}\text { Headache and } \\
\text { bilateral visual field } \\
\text { defects }\end{array}$ & $\begin{array}{l}\text { Bilateral occipital } \\
\text { mass }\end{array}$ & $\begin{array}{l}\text { Biopsy proven } \\
\text { MS with positive } \\
\text { staining for } \\
\text { myeloperoxidase, } \\
\text { CD34, CD45, } \\
\text { CD68, CD99, and } \\
\text { lysozyme }\end{array}$ & Surgical resection & $\begin{array}{l}\text { Headache resolved } \\
\text { with residual } \\
\text { visual field defects; } \\
\text { recurrence as } \\
\text { spinal masses } \\
\text { after } 5 \text { months; } \\
\text { subsequent } \\
\text { chemotherapy }\end{array}$ \\
\hline $3 \mathrm{M}$ [23] & Yes & $\begin{array}{c}\text { Acute } \\
\text { promyelocytic } \\
\text { leukaemia }\end{array}$ & $\begin{array}{c}\text { At the time of } \\
\text { diagnosis }\end{array}$ & $\begin{array}{l}\text { Proptosis of left } \\
\text { eye and facial } \\
\text { palsy }\end{array}$ & $\begin{array}{l}\text { Mass in the left } \\
\text { maxillary antrum }\end{array}$ & Not known & Chemotherapy & $\begin{array}{l}\text { Partial resolution } \\
\text { of proptosis and } \\
\text { improvement of } \\
\text { facial palsy }\end{array}$ \\
\hline $3 \mathrm{M}[24]$ & Yes & $\begin{array}{c}\text { Acute } \\
\text { lymphoblastic } \\
\text { leukaemia }\end{array}$ & After 5 years & $\begin{array}{c}\text { Headache and } \\
\text { intermittent blurry } \\
\text { vision }\end{array}$ & $\begin{array}{l}\text { Mass at right } \\
\text { cavernous sinus } \\
\text { and sella }\end{array}$ & $\begin{array}{c}\text { Biopsy of mass was } \\
\text { not done }\end{array}$ & Chemotherapy & $\begin{array}{c}\text { Symptoms } \\
\text { gradually improved }\end{array}$ \\
\hline $51 \mathrm{M}$ [25] & Yes & $\begin{array}{l}\text { Diffuse large } \\
\text { B-cell lymphoma } \\
\text { relapsed later as } \\
\text { acute myeloid } \\
\text { leukaemia }\end{array}$ & & Fever, headache & $\begin{array}{c}\text { Multiple } \\
\text { intracranial mass } \\
\text { with subarachnoid } \\
\text { haemorrhage }\end{array}$ & $\begin{array}{l}\text { Biopsy consistent } \\
\text { with AML } \\
\text { with CD43, } \\
\text { myeloperoxidase, } \\
\text { and c-kit (tyrosine- } \\
\text { protein kinase KIT) }\end{array}$ & Surgery & Not known \\
\hline
\end{tabular}

Table 1. Results of a PubMed search for central nervous system-myeloid sarcoma. AML, acute myeloid leukaemia; MS, myeloid sarcoma 


\section{REFERENCES}

1. Dores GM, Devesa SS, Curtis RE, MS Linet, Morton LM. Acute leukemia incidence and patient survival among children and adults in the United States, 2001-2007. Blood 2012;119(1):34-43.

2. Goyal G, Bartley AC, Patnaik MM, Litzow MR, Al-Kali A, Go RS. Clinical features and outcomes of extramedullary myeloid sarcoma in the United States: analysis using a national data set. Blood Cancer J 2017;7(8):e592.

3. Burns A (ed.). Observations of surgical anatomy. In: Head and neck. London, UK:Royce; 1811, p. 364

4. King A. A case of chloroma. Monthly J Med 1853;17:97.

5. Rappaport H. Tumors of the hematopoietic system. In: Atlas of tumor pathology. Washington, DC: Armed Forces Institute of Pathology; 1967 , Section III, Fascicle 8.

6. Bakst RL, Tallman MS, Douer D, Yahalom J. How I treat extramedullary acute myeloid leukemia. Blood 2011;118:3785-3793.

7. Breccia M, D'Andrea M, Mengarelli A, Morano SG, D'Elia GM, Alimena G. Granulocytic sarcoma of the pancreas successfully treated with intensive chemotherapy and stem cell transplantation. Eur J Haematol 2003;70:190-192.

8. Fitoz S, Atasoy C, Yavuz K, Gozdasoglu S, Erden I, Akyar S. Granulocytic sarcoma. Cranial and breast involvement. Clin Imaging 2002;26:166-169.

9. Aki H, Baslar Z, Uygun N, Ozguroglu M, Tuzuner N. Primary granulocytic sarcoma of the urinary bladder: case report and review of the literature. Urology 2002;60:345.

10. Pileri SA, Ascani S, Cox MC, Campidelli C, Bacci F, Piccioli M, et al. Myeloid sarcoma: clinico-pathologic, phenotypic and cytogenetic analysis of 92 adult patients. Leukemia 2007;21(2):340-350.

11. Almond LM, Charalampakis M, Ford SJ, Gourevitch D, Desai A. Myeloid sarcoma: presentation, diagnosis, and treatment. Clin Lymphoma Myeloma Leuk 2017;17(5):263-267.

12. Yang C, Liu Y, Li G, Bai J. Multifocal myeloid sarcoma in the central nervous system without leukemia. Clin Neurol Neurosurg 2014;120:99-102.

13. Cervantes GM, Cayci Z. Intracranial CNS manifestations of myeloid sarcoma in patients with acute myeloid leukemia: review of the literature and three case reports from the author's institution. J Clin Med 2015;4(5):1102-1112.

14. Piñán MA, Ardanaz MT, Guinea JM, García-Ruiz JC. Myeloid sarcoma preceding an acute promyelocytic leukaemia with neuromeningeal infiltration. Ann Hematol 2014;93(2):339-340.

15. Widhalm G, Dietrich W, Müllauer L, Streubel B, Rabitsch W, Kotter MR, et al. Myeloid sarcoma with multiple lesions of the central nervous system in a patient without leukemia. Case report. J Neurosurg 2006;105(6):916-919.

16. Yang B, Yang C, Fang J, Yang J, Xu Y. Clinicoradiological characteristics, management and prognosis of primary myeloid sarcoma of the central nervous system: a report of four cases. Oncol Lett 2017;14(3):3825-3831.

17. Cuglievan B, Menegaz BA, Garces S, Rytting ME. Acute myeloid leukaemia masquerading as a primary CNS tumour. BMJ Case Rep 2017;2017:bcr-2017-220891.

18. Imrie KR, Kovacs MJ, Selby D, Lipton J, Patterson BJ, Pantalony D, et al. Isolated chloroma: the effect of early antileukemic therapy. Ann Intern Med 1995;123(5):351-353.

19. Olar A, Lapadat R, Davidson CJ. Central nervous system involvement by myeloid sarcoma: a report of 12 cases and review of the literature. Clin Neuropathol 2016;35(5):314325.

20. Gill AS, Gill R, Kaloostian P. Intracranial myeloid sarcoma metastasis mimicking acute subdural hematoma. Case Rep Surg 2017;2017:3056285.

21. Novello M, Coli A, Della Pepa GM. Myeloid sarcoma with megakaryoblastic differentiation mimicking a sellar tumor. Neuropathology 2014;34(2):179-184.

22. Palejwala AH, O'Connor KP, Shi H. Chronic myeloid leukemia manifested as myeloid sarcoma: review of literature and case report. J Clin Neurosci 2019;64:269-276.

23. Takhenchangbam DS, Laishram RS, Thoudem TS. Proptosis and facial palsy as an unusual clinical presentation of acute myeloid leukemia. Iran J Cancer Prev 2013;6(1):52-54.

24. Heath JL, Aumann WK, Maxfield CM, Wechsler DS. Isolated central nervous system chloroma as a presenting sign of relapsed pediatric acute lymphoblastic leukemia. J Pediatr Hematol Oncol 2018;40(7):e442-e445.

25. Algharras AA, Mamourian A, Coyne T. Leukostasis in an adult with AML presenting as multiple high attenuation brain masses on CT. J Clin Diagn Res 2013;7(12):3020-3022. 